Volume 1 Nomor 2 Edisi Desember 2013
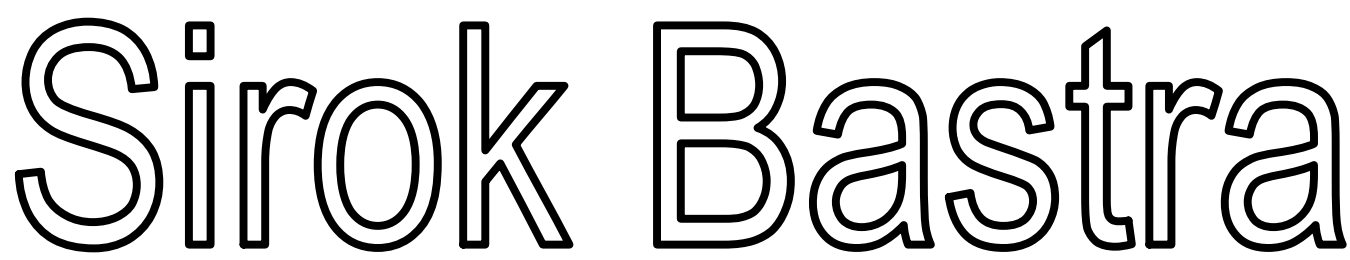

J URNAL ILMIAH KEBAHASAAN DAN KESASTRAAN

\begin{tabular}{|c|c|c|c|c|c|}
\hline $\begin{array}{c}\text { Sirok Bastra } \\
\text { Jurnal Kebahasaan dan } \\
\text { Kesastraan }\end{array}$ & Volume 1 & Nomor 2 & $\begin{array}{c}\text { Hlm. } \\
123-249\end{array}$ & $\begin{array}{c}\text { Pangkalpinang, } \\
\text { Desember } \\
2013\end{array}$ & $\begin{array}{c}\text { ISSN } \\
2354-7200\end{array}$ \\
\hline
\end{tabular}

KANTOR BAHASA KEPULAUAN BANGKA BELITUNG 

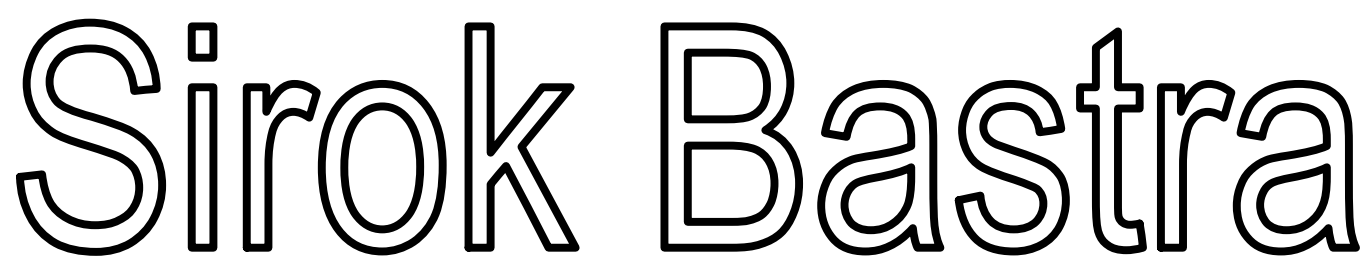

\section{J URNAL ILMIAH KEBAHASAAN DAN KESASTRAAN}

Jurnal ini merupakan wadah informasi mengenai kebahasan, kesastraan, dan pengajarannya yang memuat hasil penelitian, studi kepustakaan, dan tulisan ilmiah bidang kebahasan, kesastraan, dan pengajarannya. Jurnal ini terbit dua kali setahun, yakni Juni dan Desember, serta terbit sejak Juni 2013.

\section{Penanggung Jawab}

Kepala Kantor Bahasa Provinsi Bangka Belitung

Drs. Umar Solikhan, M.Hum.

\section{Mitra Bestari}

Prof. Dr. Agus Nuryatin, M.Hum. (Bidang Bahasa dan Pengajarannya)

Prof. Amrin Saragih, Ph.D., M.A. (Bidang Sastra dan Pengajarannya)

Dr. Felicia Nuradi Utorodewo, M.Hum. (Bidang Bahasa dan Pengajarannya)

Dr. Pujiharto, M.Hum. (Bidang Sastra dan Pengajarannya)

\section{Pemimpin Redaksi}

Rahmat Muhidin, S.S.

\section{Penyunting}

Prima Hariyanto, S.Hum.

\section{Perancang Sampul}

Feri Pristiawan, S.S.

\section{Kesekretariatan}

Khaliffitriansyah, S.Pd. Dea Letriana Cesaria, S.Hum.

Lia Aprilina, S.Pd.

Andrian Priyatno, A.Md.

Elzam

\section{Alamat Redaksi dan Penerbit}

Kantor Bahasa Provinsi Bangka Belitung

Ruko Permata 7, Jalan Solihin G.P. Km 4, Pangkalpinang, Kep. Bangka Belitung

Telp./Faks.: 0717-438455, Pos-el: sirokbastra@gmail.com

Pemuatan suatu tulisan dalam jurnal ini tidak berarti redaksi menyetujui isi tulisan tersebut. Isi tulisan menjadi tanggung jawab penulis. Tulisan telah ditinjau oleh mitra bestari. Setiap karangan dalam jurnal ini dapat diperbanyak setelah mendapat izin tertulis dari penulis, redaksi, dan penerbit. 


\section{KATA PENGANTAR}

Puji syukur ke hadirat Pemilik dan Pencipta semesta ini yang memiliki kuasa atas diri-Nya sendiri. Dialah Tuhan Yang Maha Esa yang telah memberikan rahmat dan hidayah-Nya sehingga Volume 1 Nomor 2 Jurnal Sirok Bastra dapat terbit tepat pada waktunya.

Pada nomor kedua ini, dimuat sebelas tulisan, yakni enam tulisan kebahasaan, empat kesastraan, dan satu pengajaran sastra. Dari segi bahasa, sebagian besar tulisan disajikan dalam bahasa Indonesia, hanya dua tulisan yang disajikan dalam bahasa Inggris. Kami mengucapkan terima kasih kepada para penulis yang telah bersedia menerbitkan karya mereka pada edisi ini. Para penulis merupakan para peneliti, pakar, dosen, dan mahasiswa dari berbagai perguruan tinggi dan instansi. Terima kasih juga kami sampaikan kepada para mitra bestari kami yang telah memberi ulasan terhadap tulisan-tulisan yang masuk ke redaksi.

Demi memenuhi keberagaman isi dan penulis, Sirok Bastra membuka kesempatan bagi para peneliti dan penulis menyampaikan hasil penelitian dan pemikiran mutakhir dalam bidang kebahasaan, kesastraan, dan pengajarannya.

Pangkalpinang, Desember 2013

Tim Redaksi 


\section{UCAPAN TERIMA KASIH UNTUK MITRA BESTARI}

Redaksi Sirok Bastra mengucapkan terima kasih kepada para mitra bestari yang telah meninjau, menimbang, dan mengulas makalah-makalah yang diterbitkan dalam Sirok Bastra Volume 1 Nomor 2, edisi Desember 2013, yakni

Prof. Dr. Agus Nuryatin, M.Hum.

Bidang Sastra dan Pengajarannya

Universitas Negeri Semarang

Semarang, Jawa Tengah

Prof. Amrin Saragih, Ph.D., M.A.

Bidang Bahasa dan Pengajarannya

Universitas Negeri Medan

Medan, Sumatra Utara

Dr. Felicia Nuradi Utorodewo, M.Hum.

Bidang Bahasa dan Pengajarannya

Universitas Indonesia

Depok, Jawa Barat

\section{Dr. Pujiharto, M.Hum.}

Bidang Sastra dan Pengajarannya

Universitas Gadjah Mada

Yogyakarta, Daerah Istimewa Yogyakarta 


\section{DAFTAR ISI}

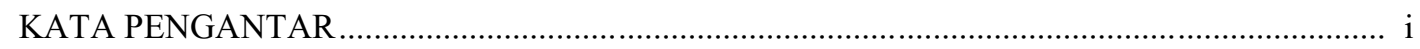

UCAPAN TERIMA KASIH UNTUK MITRA BESTARI .................................................... ii

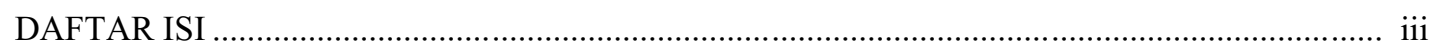

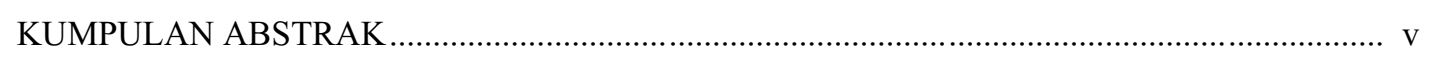

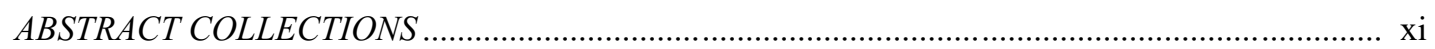

BAHASA INDONESIA DALAM INFORMASI DAN IKLAN DI RUANG PUBLIK KOTA PANGKALPINANG

(Indonesian in Information and Advertising in Public Space Pangkalpinang)

Umar Solikhan $123-129$

PERBEDAAN MAKNA NOMINA BERAFIKS $P E-, P E R-, P E--A N$, DAN $P E R--A N$ DALAM NASKAH HIKAYAT BAYAN BUDIMAN, HIKAYAT MUHAMMAD HANAFIYYAH, DAN HIKAYAT RAJA PASAI

(Affixed Noun Meaning Differences of pe-, per-, pe--an, and per--an in The Hikayat Bayan Budiman, Hikayat Muhammad Hanafiyyah, and Hikayat Raja Pasai Manuscripts)

Rindias H. Fatmasari $131-147$

WACANA RUBRIK INTIMATE DI MAJALAH DIGITAL INTERAKTIF MALE

(Intimate Rubric in Male Digital Interactive Magazine Discourse)

Prima Hariyanto $149-160$

AN ACOUSTICAL CONTRASTIVE ANALYSIS OF SUNDANESE CENTRAL VOWELS (Analisis Konstrastif Akustik Vokal Pusat Bahasa Sunda)

Yusup Irawan. $161-175$

KATA SUDAH SEBAGAI PENANDA ASPEK DENGAN AWALAN TER-

The Word of Sudah as An Aspect with Prefix Ter-

Dea Letriana Cesaria $177-182$

PERUBAHAN DAN PERGESERAN MAKNA DALAM KATA-KATA BERDERIVASI NOMINA KE VERBA YANG MENGANDUNG AFIKS $M E(N)-, M E(N)-K A N$, DAN $M E(N)-I$ PADA SURAT KABAR HARIAN KOMPAS

(Change and Shift of Meaning in The Derivated Words Nomine to Verb That Contain Affixes $m e(N)-$, me(N)-kan, dan me(N)- $i$ in The Kompas The Daily Newspaper)

Teodora Nirmala Fau $183-193$

MENCIPTA-KREATIF NASKAH DRAMA DENGAN STRATEGI MENULIS TERBIMBING (Creative Writing of Playscript eith Guided Writing Strategy)

Sony Sukmawan. $195-205$ 
PENGARUH KONSEP HAGABEON, HAMORAON, DAN HASANGAPON TERHADAP

KETIDAKSETARAAN GENDER DALAM AMANG PARSINUAN

(The Influence of Hagabeon, Hamoraon, and Hasangapon Concept for Gender Inequality in Amang Parsinuan)

Fransiska Simangunsong $207-220$

PERSPEKTIF PENGARANG MENGENAI RELASI ANTARA MANUSIA DAN

LINGKUNGAN HIDUP DALAM NOVEL PARTIKEL KARYA DEWI LESTARI: SEBUAH KAJIAN EKOKRITISISME

(Author's Perspective on The Relationship Between Humans and The Environment in The Novel Partikel Written by Dewi Lestari: an Ecocriticism Studies)

Alfi Yusrina Ramadhani $221-229$

FENOMENA HUKUM ADAT BALI TERHADAP BAYI KEMBAR BUNCING DALAM

NOVEL INCEST KARYA I WAYAN ARTIKA

Bali Custom Law Phenomenon of Kembar Buncing Infant in I Wayan Artika Novel Incest Annisa Aprinandri Irwin dan Khansa Khairunnisa $231-241$

RELIGIOUS AND MORAL VALUES IN MADURA FOLKTALES

Religiositas dan Nilai Moral dalam Cerita-Cerita Rakyat Madura

Imron Wakhid Harits. $243-249$ 
Yusup Irawan: An Acoustical Contrastive Analysis of Sundanese Central Vowels

\title{
AN ACOUSTICAL CONTRASTIVE ANALYSIS OF SUNDANESE CENTRAL VOWELS
}

\author{
Analisis Konstrastif Akustik Vokal Pusat Bahasa Sunda \\ Yusup Irawan \\ Balai Bahasa Provinsi Jawa Barat \\ Jalan Sumbawa Nomor 11, Bandung 40113, telp. 022-92455752 \\ e-mail: yuswanx@yahoo.co.id
}

(diterima 19 Juli 2013, disetujui 30 September 2013, revisi terakhir 28 Oktober 2013)

\begin{abstract}
The first, this research is intended to identify acoustic profiles of the two central vowels in Sundanese, viz / / and /o/. The second, this research is intended to searches the acoustic contrasts between the two vowels. Experimental method was applied in this research. The result shows that vowel / / has higher first fromant (F1) than vowel /ö/ both at opened syllable and at closed syllable. However, for the other acoustic properties- the second formant (F2), fundamental frequency (Fo), duration (ms), and intensity (dB)—vowel /ö/ has higher acoustic values than vowel / /. In correlation with the second research objective, viz to search acoustic properties which contrast the two central vowels, it's found that all acoustic properties (F1, F2, Fo, duration and intensity) contrast the two Sundanese central vowels. All statistical tests which were applied show the results that there are significant differences of the acoustic properties between both central vowels.
\end{abstract}

Key words: acoustical analysis, Sundanese, central vowel

\begin{abstract}
Abstrak
Pertama, penelitian ini bertujuan untuk mengidentifikasi profile akustik dua vokal pusat dalam bahasa Sunda, yaitu / / dan /ö/. Kedua, penelitian ini bertujuan mencari kontras akustik di antara dua vokal tersebut. Metode eksperimental diaplikasikan dalam penelitian ini. Hasil menunjukkan bahwa vokal / / memiliki forman pertama (F1) yang lebih tinggi daripada vokal /ö/ baik di suku kata terbuka, maupun di suku kata tertutup. Namun, untuk properti akustik lainnya_forman kedua (F2), frekuensi fundamental (Fo), durasi (ms), dan intensitas (dB) vokal /ö/ memiliki nilai akustik yang lebih tinggi daripada vokal / /. Kaitannya dengan tujuan kedua penelitian ini, yaitu mencari properti akustik yang mengontraskan kedua vokal pusat tersebut, diketahui bahwa semua properti akustik (F1, F2, Fo, durasi dan intensitas) mengontraskan kedua vokal pusat bahasa Sunda tersebut. Semua uji statistik yang digunakan menunjukkan hasil bahwa ada perbedaan signifikan properti-properti akustik di antara kedua vokal pusat tersebut.
\end{abstract}

Kata kunci: analisis akustik, bahasa Sunda, vokal pusat

\section{INTRODUCTION}

\subsection{Background}

Sundanese is one of local languages in Indonesia. The language is spoken by most people in West Jawa and Banten Province. It is considered as a local language with significant number of speakers. The data released by Ethnologue SIL (1996) stated that about 27 million speakers use the language as their first language. Therefore, the data positioned Sundanese at the rank 43rd among 100 top languages.

Historically, linguistic studies on Sundanese have been done since Dutch colonial era. In the era, most of the researchers came from the country, such as
G.J. Grashuis, A. Geerdink, and S. Coolsma. G.J. Grashuis wrote Over de verbale vormen in het Soendaneesch (1873) 'Verb in Sundanese'. A. Geerdink wrote Soendaneesch-Hollandsch Woordenboek (1875). Meanwhile, S. Coolsma wrote Soendaneesche Spraakkunst (1904) 'Sundanese Grammar'. Considering significant contribution of the Dutch scholars on Sundanese linguistic studies, we should not ignore their merit.

After Indonesia proclaimed its independence 1945, Sundanese studies are not dominated by Dutch researchers anymore. Non-Dutch scholars, such as R.H. Robins, J. Kats and Indonesian linguists, such as 
D.K. Ardiwinata, Ayatrohaedi, Fatimah Djadjasudarma, and Yus Rusyana play more important roles in Sundanese linguistic studies than Dutch researchers. Now, many more young Indonesian linguists research Sundanese. They study Sundanese from different aspects, from grammatical aspects until nongrammatical aspects, such as sosiolinguistics and pragmatics.

Although a lot of linguists have studied Sundanese in many aspects, the sound aspect of the language is frequently overlooked. Consequently, at present we have difficulties to find a complete sound description of Sundanese. Some linguists tried to describe the phonological structure of Sundanese. However, except physiological description of Sundanese phonemes, up to now, we still have no acoustical description of Sundanese phonemes. The lack of Indonesia linguists' knowledge on acoustic phonetic and speech analyzer causes the condition that until know we have no acoustical description of Sundanese phonemes. That's why this research was conducted.

Sundanese has three central vowels: /a/, / /, dan /ö/. From the three central vowels, two central vowels (/ / dan /ö/) are interesting to study from acoustical perspective with some reasons. First, vowel / / dan /ö/ become special characteristics of Sundanese sound because not all local languages in Indonesia have the sounds, such as Batak Toba. Second, although Indonesian, Javanese, and other local languages have vowel / /, but they have no vowel /ö/. Aceh and Bali have /ö/, but acoustically the vowel has different quality from vowel /ö/ spoken by Sundanese. Third, exploring vowel / / dan /ö/ acoustically by using contrastive analysis can provide clearer physical description of the vowel positions in articulatory aspect. The description of the vowels is helpful for non-Sundanese in the matter of how to articulate them. The last, description of the two Sundanese vowels gives contribution to the study of Sundanese sound aspect.

\subsection{The Statement of The Problem}

As it's mentioned that Sundanese has three central vowels, viz /a/, / /, dan /ö/. This research focused on the acoustic properties of the vowel //, dan /ö/. Therefore, it is formulated that the statements of the research problems as follows. First, How is the general acoustic profile of the two central vowels in Sundanese? Second, in what acoustic properties the two vowels contrast each other?

\subsection{The Objective of The Research}

Based on the statements of the problems above, the research searched the acoustic profile of two Sundanese central vowels, viz vowel / / dan /ö/. At the higher level, this research searched the acoustic contrasts between the two vowels.

\subsection{Method}

An experimental method for gaining data and acoustical contrastive analysis were applied for this research. To earn the data (sound of the vowels), a minimal pair was used. In the minimal pair, the Sundanese central vowels are contextualized in the same sound evironment. We chose two words as a minimal pair with syllable pattern KV-KVK. The words with that sound pattern enable us to locate vowels [ö] and [ ] both in opened and closed syllable. Therefore, we used the minimal pair is lebet $\left[\begin{array}{lll}1 & b & t\end{array}\right]$ 'come in' and leubeut [löböt] 'very fruitful'.

A selected male informan was used to gain sound data of vowel / / and /ö/. He was requested to say the minimal pair (lebet and leubeut) in a constant intonation. The informan is a Sundanese native speaker with the age 35 years old. The informan use Sundanese in in his daily life.

The recording instrument which was used to record was PRAAT which had been installed in a notebook ASUS A43S Series. The notebook was trusted to have good capacity to record. For the further analysis, acoustical analysis and statistical analysis, the research used PRAAT series 5.310 and SPSS 18.

\section{THEORETICAL GROUND}

\subsection{Sundanese Vowel System}

From the view of the vowel inventory, Sundanese has more vowels than Indonesian. Indonesian has six vowels, viz /a/,/i/, /u/, /e/, /o/, dan / /. On the other side, Sundanese has seven vowels, viz /a/,/i/, /u/, /e/, /o/, / /, dan /ö/ (Robins, 1980:180, Nothofer, 1980:56, Djajasudarma, 1994:18 in Sugiyono, 2006; Sudaryat, 2010:29). The prominence difference between the two languages is Indonesian has two 
central vowels, viz /a/ and / /, whereas Sundanese has three central vowels, viz /a/, / / dan /ö/.

In Sundanese, It is easy to find words with vowel //, such as belet 'stupid', lebet 'come in, embé 'goat', emih 'mother', endog 'egg', metet 'full', caket 'close', dan lemes 'soft'. The vowel / / distribution can be at the opened syllables or at the closed syllable. However, vowel / / cannot locate at the last syllable with opened syllables. It is also easy to find words with vowel /ö/ in Sundanese, such as beuruem 'red', meuruen 'may be', seuseuh 'wash', leuleus 'weak', beuteung 'stomach', and leubeut 'very fruitful'. Like vowel / /, vowel /ö/ distribution can be at opened syllable or at closed syllable. However, vowel /ö/ can locate at the last syllables with opened syllables.

The vowel positions in vowel chart can be view below. It is seen that the charts show different positions of Sundanese vowel. This may happens because the linguists applied impressionic approach.

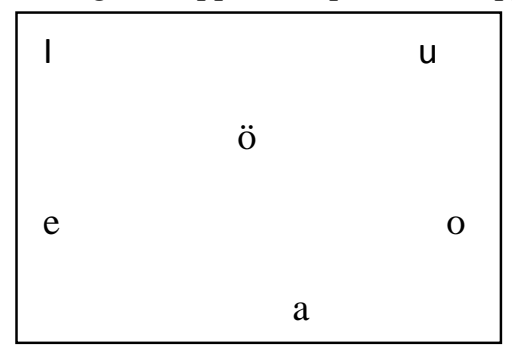

Pic. 1: Sundanese vowel position according to Sugiyono (2006)

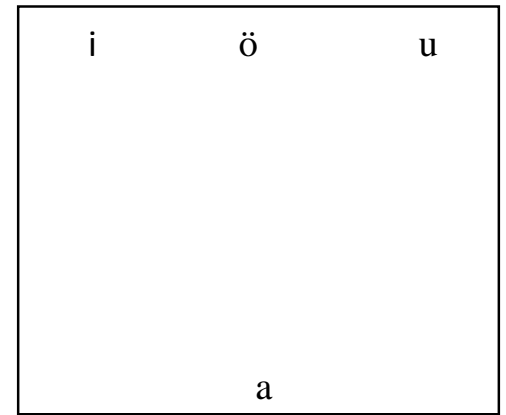

Pic. 2: Sundanese vowel position according to Crothers (1978 in van Zanten, 1989).

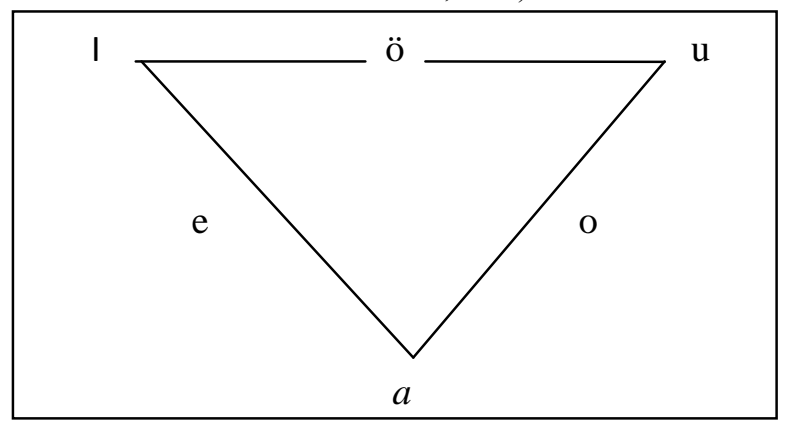

Pic. 3: Sundanese vowel position according to Sudaryat, et al.

(2010)
Generally, the three charts describe that vowel /i/ is a high-front-unrounded vowel. The vowel is realized as [i]. Vowel /e/ is a midle-front-unrounded vowel. It is realized as [e] or [E]. Vowel / / is a midlecentral-unrounded vowel. The vowel is realized as [ ]. Vowel /o/ is a midle-back-rounded vowel. The vowel is realized as [o] or [0]. Vowel/ö/ is a highcentral-unrounded vowel. It is realized as [ö]. Vowel /a/ is a low-central-unrounded vowel. It is realized as [a]. Vowel $/ \mathrm{u} /$ is a high-back-rounded vowel. The vowel realized as $[\mathrm{u}]$ atau $[\mathrm{U}]$.

In orthographic system, the alphabets which represent the vowels /a/, /i/, /u/, and /o/ are a, i, u, and o, while vowels /e/, / /, and /ö/ are represented by é, $\mathrm{e}$, and eu. Among the seven vowels that Sundanese has, vowel /ö/ is very difficult for non-Sundenese to articulate because most of the local languages in Indonesia have no the vowel and so does Indonesian.

Balinese and Acehnese are two local languages which have vowel [ö] like in Sundanese. The same as in Sundanese, in Acehnese, the vowel can locate at opened and closed syllables, whereas in Balinese, the vowel can be only at the last syllables of words and opened syllables. The alphabet which represents the vowel in orthographic system in Balinese is $a$, while in Acehnese, the alphabet which represents the vowel is $e u$.

\subsection{Theoretical Ground}

\subsubsection{Formant}

Formant frequency is the most important vowel acoustic property (Ladefoged, 2007: 2007: 104). Generally, vowel sounds are characterized by the first formant (F1) and the second formant (F2), but the third formant (F3) is needed to measure when indentifying front-high vowel (Ladefoged, 2007: 104). Physiologically, F1 corresponds with the degree of mouth opening. The larger of the mouth opening, the higher will be the F1 frequency. In converse, the smaller of the mouth opening, the lower will be the F1 frequency. The frequency of F1 also corresponds with how high or how low of tongue position. If a tongue position is higher when it is voicing a vowel, the $\mathrm{F} 1$ frequency will be lower. If the tongue position is lower, coversely the F1 frequency will be higher.

The second formant (F2) physiologically correspond with part of the tongue which acts during 
voicing vowel. The back vovels are characterized by the back part of the tongue. The front vowel are characterized by the front part of the tongue. The frontier of the vowel sound, the higher will be the F2 frequency. Coversely, back vowels would have lower frequencies.

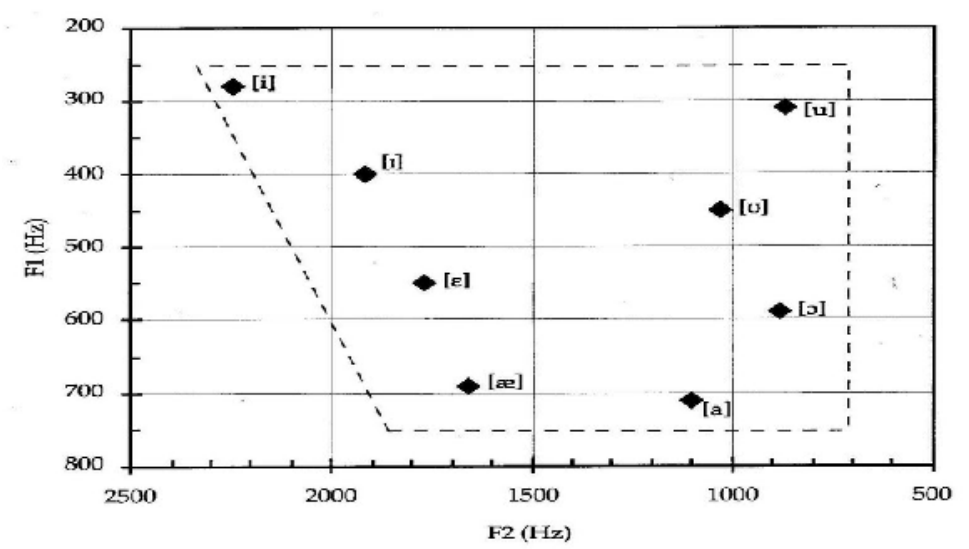

Pic. 4: Example of vowel chart of some English vowels with F1 and F2 description

\subsubsection{Fundamental Frequency (Fo)}

Fundamental frequency (Fo) is an acoutical property which physiologically correlates with the vibration frequency of vocal fold. The faster the vocal fold vibrates, the higher the Fo will be. Acoustically, Fo is represented in form of sound waves. There are two kinds of sound wave: periodic and unperiodic sound wave. Periodic sound wave is characterized by regular wave cycles, whereas unperiodic sound wave is characerized by irregular wave cycles. In phonetic studies, periodic sound wave plays more important role than unperiodic wave because phoneticians usually use periodic wave as object of their studies.

Sound wave of vowels is periodic sound wave. It has regular wave cycles. However, sound wave of vowel is not a sinple sound wave. It is a complex sound wave. A complex sound wave doesn't consist of a wave. It is a combination of more than a wave which is usually called harmonic. The first harmonic is called fundamental frequency. That is a wave in a complex sound wave which has the lowest frequency cycles.

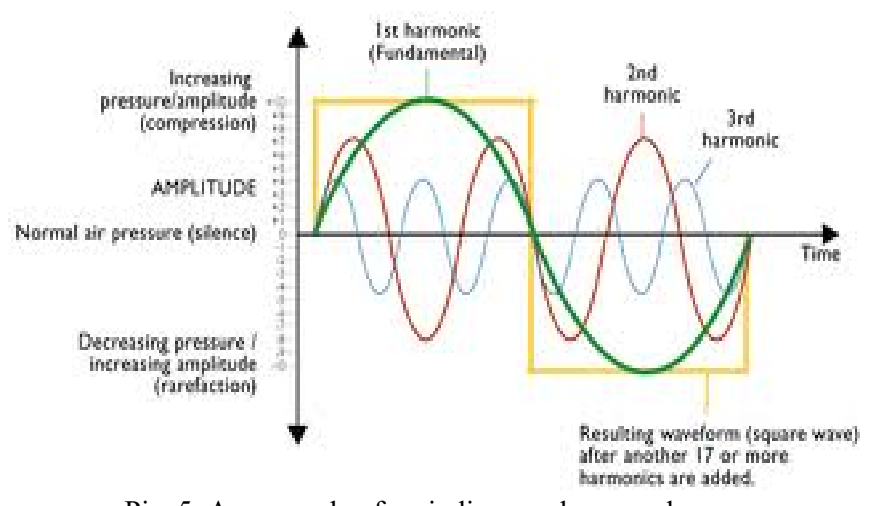

Pic. 5: An example of periodic complex sound wave

In phonetic studies, commonly the first harmonic or Fo is used as standard measurement to identify acoustic property of speech sound. Picture 5 shows an example of a periodic complex sound. The Fo is reperesented by the thickest sound wave, while the second and the third harmonic are represented by higher frequency cycles.

\subsubsection{Duration}

Duration or quantity is the time length which is needed to segment speech sound. Duration is an important element of temporal structure of speech. Time aspect determines characteristics of speech sound segment, such as syllables, words, sentences, even pharagraphs. In oral languages, the boundaries of syllables, words and sentence are marked by duration. The aspect of duration must not ignored, a 
complete description of a language should include a description of its individual sounds of the language because intrinsic duration of individual sounds of languages are not the same.

Theoretically, physilogically speech duration is influenced by biomechanic factor. For example, vowel [i] tends to be longer than vowel [a] or [e]. This because when voicing [i], we need more effort than voicing vowel [a] or [e]. Usually, speech duration is represented in second or milisecond (ms). One second equals with one thousand milisecond.

\subsubsection{Intensity}

Perceptually, intensity is perceived as loudness of speech sound. Physiologically, the degree of intensity is greatly influenced by the air capacity which passes through the glottis. The air flow happens due to the different pressure berween subglottal and supraglotal organ. If the air flow is greater, it will create higher intensity and persetually, will increase the loundness. Generally, intensity is measured with decibel scale (dB). Intensity correlate with sound amplitude. A greater amplitude will create greater intensity. Picture 6 describes amplitude of a sound wave.

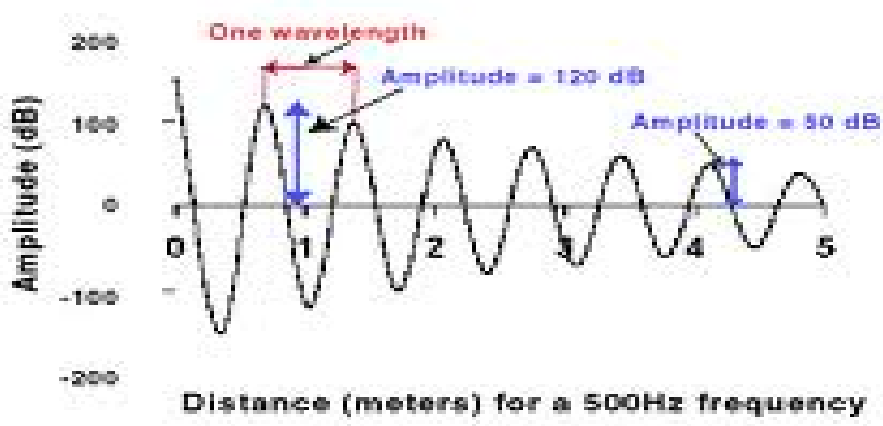

Pic. 6: An example of sound amplitude

Picture 6 above describes how the amplitude of a sound is getting lower from $120 \mathrm{~dB}$ to $50 \mathrm{db}$ as the sound is away from the source of the sound. The degree of intensity is formulated with the fomulation $\boldsymbol{n}=\mathbf{1 0} \log (\boldsymbol{I} / \mathbf{I o}) . n$ is intensity in decibel scale $(\mathrm{dB})$ and $I o$ is intensity referent. Commonly, intensity referent is $10^{-16}$ watt per $\mathrm{cm}^{2}$ (Lehiste, 1970:113).

\section{RESULT}

\subsection{Formant Analysis}

After recording the target words (lebet and leubeut) spoken by informan, the acoustic properties of the vowel / / and /ö/ were indentified and inputed in statistics data editor SPSS 18 for further statstics tests. The informan spoke the word lebet and leubeut for 34 times each. So, there are 68 times vowel / / spoken by the informan which are devided into two categories: opened syllable and closed syllable. On the other hand, there are also were 68 times vowel /ö/ spoken by the informan devided into two categories: opened syllable and closed syllable. The acoustic properties of the vowels spoken by informan were indentified including the first formant, the second formant, Fo, duration, and intensity.

Normality test (one-sample kolmogorov smirnov test) was done for the acoustic data of the two vowels. The result shows that the data distributions of the two vowels in opened syllable (first syllable) are normal $(\mathrm{p}>0,05)$, except for $\mathrm{F} 2$ of the vowel / / $(\mathrm{P}=0.047, \mathrm{p}<0.05)$. The result also shows that the data distributions of the two vowels in closed syllable (second syllable) are normal $(p=0.015, p>0,05)$, except for F2 and intensity of the vowel / / $(\mathrm{p}=0.045$, $\mathrm{p}<0.05)$.

We can see the general acoustic profile of the vowel / / and /o/ both at the opened syllable and closed syllable represented by the picture 7 and 8 below. However, the acoustic data of the vowels specifically can be seen in table 1 and table 2 . In the picture 7 and 8 we can see the mean values of each acoustic component we identified from the vowel / / and /o/ both in at the opened syllable and closed 
syllable. We have explained that those vowels were

leubeut [löböt].

inserted in a minimal pair lebet $\left[\begin{array}{lll}1 & \mathrm{~b} & \mathrm{t}\end{array}\right]$ 'come in' and

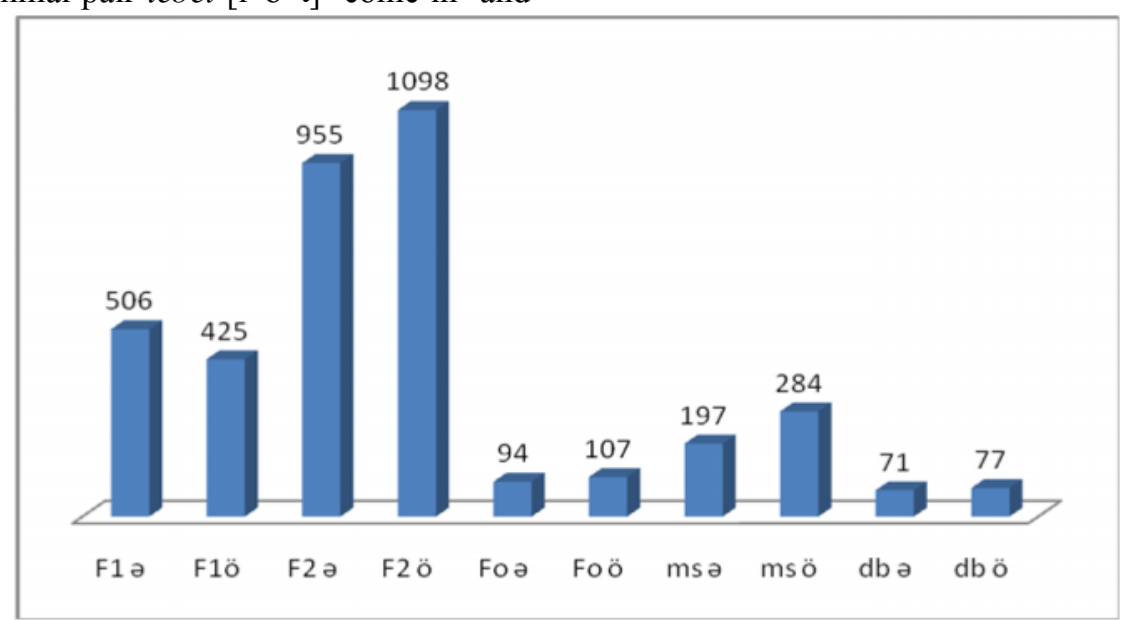

Pic. 7: Acoustic property means of vowel / / and /ö/ at the opened syllable

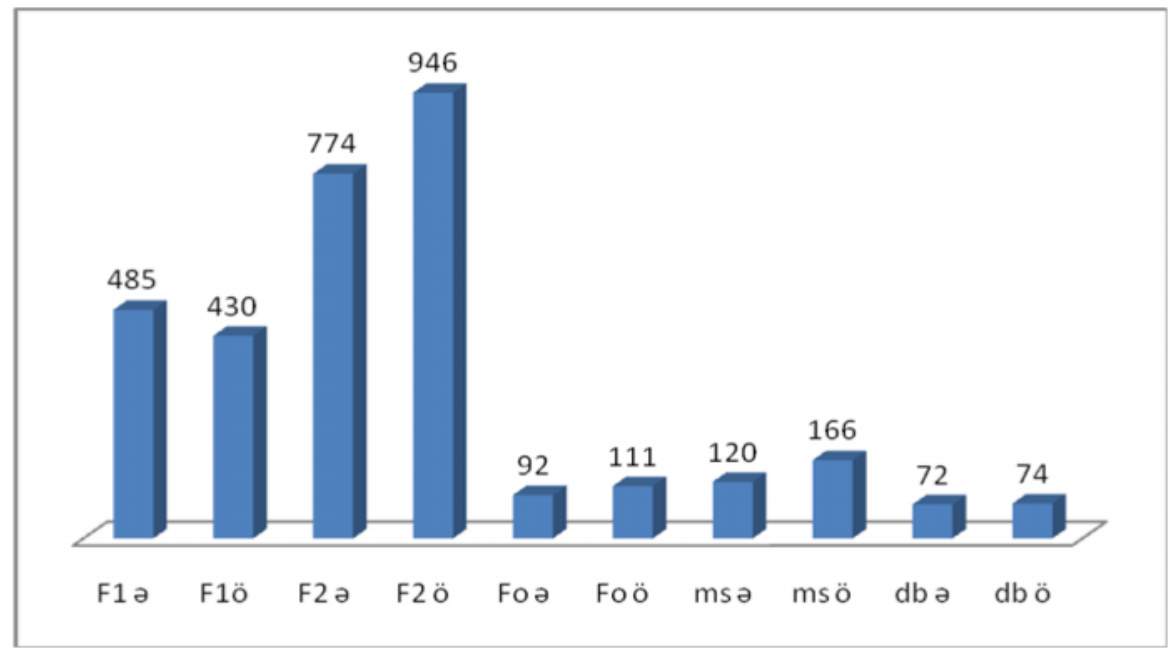

Pic. 8: Acoustic property means of vowel / / and /ö/ at the closed syllable

We can see that there is consistent pattern between the data in picture 7 and picture 8 . In the table 7 , we can see that vowel / / has higher F1 than vowel /ö/ at opened syllable (first syllable). However, vowel / / has lower F2 than vowel /ö/. Generally, for the other acoustic properties (F2, Fo, ms, and $\mathrm{dB}$ ) vowel /ö/ has more acoustic values than vowel //. Picture 8 represents the same data pettern as picture 7. It shows that vowel /ö/ has more acoustic values for the acoustic properties F2, Fo, ms, and dB, Whereas vowel / / only has acoustic value for F1.

\subsubsection{First Formant (F1) Analysis}

As it is stated before, the first formant is an acoustic property which corelates with the height of tongue position when articulating vowels. First formant (F1) value correlates inversely with the height of tongue position. The higher the tongue, the lower of vowel F1 frequency. The lower the tongue, the higher of vowel F1 frequency.

The data in table 1 shows the difference value of F1 frequency means between vowel / / and vowel /ö/ in opened syllable (first syllable). The F1 frequency mean of vowel / / at the opened syllable of the word $/ 1 \mathrm{~b} \mathrm{t} /$ is higher $(507 \mathrm{~Hz})$ than the $\mathrm{F} 1$ frequency mean of vowel /ö/ at the opened syllable of the word /löböt/ $(425 \mathrm{~Hz})$. The acoustic distance of F1 frequency between the two means is $82 \mathrm{~Hz}$. ). This data indicates that the informan realized the vowel / / with lower tongue position than the vowel /o/. A T-test (two tailed independence sample test) was done to assess whether the mean of the two data groups (F1 vowel / / and F1 vowel /ö/) are statistically different from each other. The result shows that there is a significant difference of $F 1$ between the two vowels in opened vowel $(\mathrm{p}=0.000, \mathrm{P}<0.05$. 
Comparison analysis of F1 frequency means between vowel / / and vowel /ö/ at the closed syllable (second syllable) of the word / $1 \mathrm{~b} \mathrm{t} /$ and /löböt/ in table 2 shows the same nature as the data of F1 in table 1. The F1 frequency mean of vowel / / at the closed syllable of the word $/ 1 \mathrm{~b} \mathrm{t} /$ is still higher $(485 \mathrm{~Hz})$ than the F1 frequency mean of vowel /ö/ at the same syllable of the word /löböt/ $(430 \mathrm{~Hz})$. The acoustic distance of F1 frequency between the two means is $55 \mathrm{~Hz}$. This data, again, indicates that the informan realized the vowel / / with lower tongue position than the vowel /ö/.

A T-test (two tailed independence sample test) was done to assess whether the means of the two group data, F1 of vowel / / and F1 of vowel /ö/, are statistically different. The result shows that there is a significant difference between the F1 means of the two vowels in opened vowel $(\mathrm{p}=0.000, \mathrm{P}<0.05)$.

The broadband spectrogram (picture 9) is a supporting acoustic evidence of how vowel / / both in opened syllable and in closed syllble was realized with lower tongue position than realization of vowel /o/. The F1 contour of the vowel / / in the word lebet (first contour) is higher than F1 contour of the vowel /ö/ in the word leubeut (second contour). Both contours represent that vowel / / (in Sundanese) is realized with lower tongue position than the vowel /ö/.

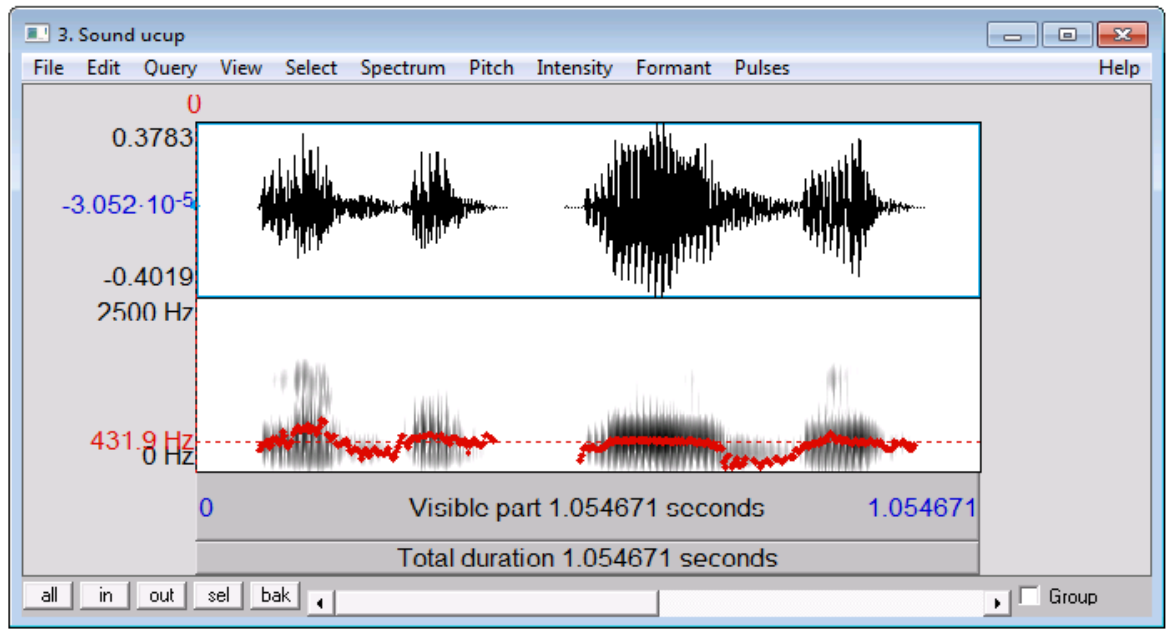

Pic. 9: Waveform and F1 contour of the word lebet (first contour) and leubeut (second contour) spoken by informan with window length $10 \mathrm{~ms}$

\subsubsection{Second Formant (F2) Analysis}

We have explained that the second formant (F2) physiologically corresponds with part of the tongue which acts during voicing vowel. The back vovels are characterized by the back part of the tongue. The front vowel are characterized by the front part of the tongue. The frontier of a vowel sound, the higher will be of its F2 frequency. Coversely, back vowels would have lower frequencies than their conterparts.

The data in table 1 shows the difference value of F2 frequency means between vowel / / and vowel /ö/ in opened syllables (first syllable). The F2 frequency mean of the vowel / / at the syllable of the word $/ 1 \mathrm{~b} \mathrm{t} /$ is lower $(955 \mathrm{~Hz})$ than the F2 frequency mean of vowel /ö/ at the same syllble of the word /löböt/ $(1098 \mathrm{~Hz})$. The acoustic distance of F2 frequency between the two means is $142 \mathrm{~Hz}$. Analysis on the data in table 1 shiows that there are 16 data with frequency above $1000 \mathrm{~Hz}$ belong to vowel / /. On the other hand, there 23 data with frequency above $1000 \mathrm{~Hz}$ belong to vowel /ö/. This data shows that the informan realized the vowel /ö/ with the frontier part of the tongue than the realization of the vowel / /.

There is another data analysis we should consider. The data distribution of F2 in table 1 is abnormal. This is why we used a nonparametrik test (Mannwhitney-wicolcon test). Further more, we found that there is a large data range. The lowest F2 of vowel / / is 533, while the highest F2 is 1331 . So, there is a wide acoustic distance between the lowest and the highest value $(798 \mathrm{~Hz})$. We can see the same characteristics as F2 of vowel /ö/. The lowest F2 of vowel /ö/. is 465 , while the highest F2 is 1440 . So, the acoustic distance between the lowest and the highest value is $(975 \mathrm{~Hz})$. This data indicates that the two vowels have a large vowel space. 
A Mann-whitney-wicolcon test has been done to assess whether the means of two group data (F2 vowel / / and F2 vowel /ö/) are statistically different. The wicolcon test was done due to the abnormality of the data distribution. The result shows that there is a significant difference of F2 between the two vowels in opened vowel $(\mathrm{P}=0,037 \mathrm{p}<0,05)$.

Comparison analysis of F2 frequency means between vowel / / and vowel /ö/ at the closed syllable (second syllable) of the word / $\mathrm{b} \mathrm{t} /$ and /löböt/ in table 2 shows the same charactersitics as the data of F2 in table 1. The F2 frequency mean of vowel / / at the closed syllable of the word $/ 1 \mathrm{~b} t /$ is lower $(774 \mathrm{~Hz})$ than the F2 frequency mean of vowel /o/ at the same syllable of the word /löböt/ $(946 \mathrm{~Hz})$. The acoustic distance between the two means is $172 \mathrm{~Hz}$. We also found that there is a large data range. The lowest F2 of vowel / / is 511, while the highest F2 is 1437. So, there is a wide acoustic distance between the lowest and the highest value $(926 \mathrm{~Hz})$. We can see the same characteristics as F2 of vowel /ö/. The lowest F2 of vowel /o/. is 582, while the highest F2 is
1379. The acoustic distance between the lowest and the highest value is $(797 \mathrm{~Hz})$. This data also indicates that the two vowels have a large vowel space.

A Mann-whitney-wicolcon test has been done to assess whether the means of two groups (F2 vowel / / and F2 vowel /ö/) are statistically different from each other. The result shows that there is a significant difference of $\mathrm{F} 2$ between the two vowels in closed vowel $(\mathrm{P}=0,002 \mathrm{p}<0,05)$. The data, we gain, indicates that the informan realized the vowel /o/ with the frontier part of the tongue than the realization of the vowel / /.

The broadband spectrogram (picture 10) can be a supporting evidence of how vowel //ö/ both in opened syllable and in closed syllble was realized with frontier part of the tongue than the realization of the vowel / /. The F2 contour of the vowel /ö/ in the word leubeut (second contour) is relatively higher than F2 contour of the vowel /ö/ in the word lebet (first contour). The contours represent that vowel /o/ (in Sundanese) is realized with frontier part of the tongue than the realization of the vowel / /.

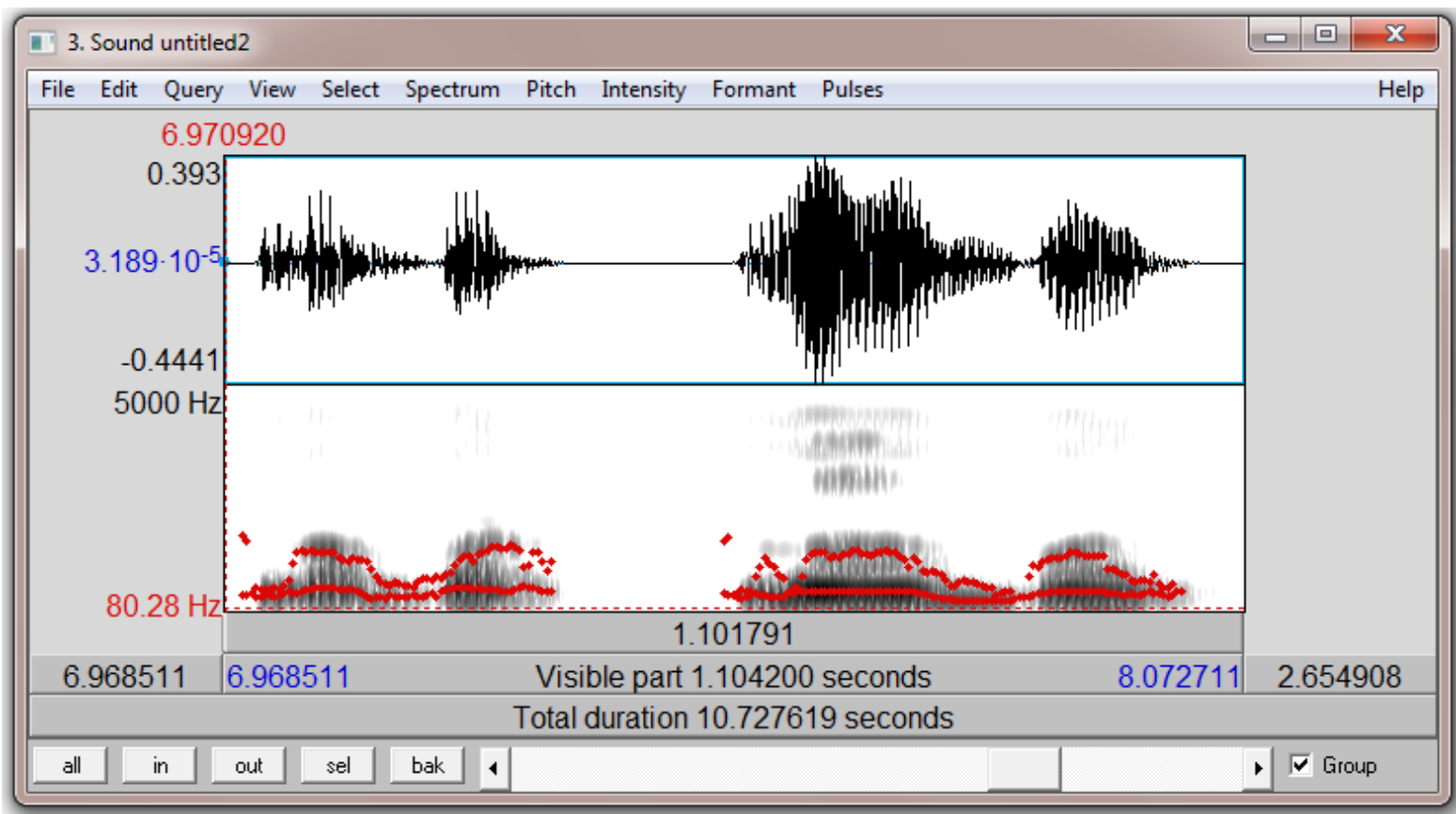

Pic. 10: Waveform and F2 contour (second dotted line from below) of the word lebet and leubeut spoken by informan with window length $20 \mathrm{~ms}$

\subsection{Fundamental frequency Analysis}

Fundamental frequency (Fo) is an acoustic property which physiologically correlates with the vibration frequency of vocal fold. The faster, the vocal fold vibrates, the higher, the higher, the Fo will be. Perceptually, we hear Fo as pitch.

Comparing the Fo value between vowel / / dan /ö/ at the opened syllable of the word lebet and leubeut in table 1, we found that Fo of vowel /ö/ is always higher 
than Fo of vowel / /. So, its not surprising that Fo mean of vowel /ö/is higher too than Fo mean of vowel / /. From Fo data in table 1 we can count that the acoustic distance between the two means is $13 \mathrm{~Hz}$. A T-test (two tailed independence sample test) was done to assess whether the means of the two groups, Fo of vowel / / and Fo of vowel /ö/ are statistically different each other. The result shows that there is a significant difference between the Fo means of the two vowels in opened vowel $(\mathrm{p}=0,000 ; \mathrm{p}<0,05)$.

In table 2 the data indicates that Fo between vowel $/ \ddot{\mathrm{o}} /$ and vowel / / h in closed syllable (second syllable) has different value. Fo of vowel /ö/ is always higher that Fo of vowel / /. When we make deeper analysis we can see that Fo of vowel /ö/ is always above $100 \mathrm{~Hz}$. Meanwhile, Fo of vowel / / always below $100 \mathrm{~Hz}$. So, again, its not surprising that the data in table shows Fo mean of /ö/ than Fo mean of / /. A Ttest (two tailed independence sample test) was done to assess whether the means of the two groups, Fo of vowel / / and Fo of vowel /ö/ are statistically different each other. The result shows that there is a significant difference between the Fo mean of the two vowels in closed vowel $((p=0,000 ; p<0,05)$.

This data, we explain, shows that physiologically when a sundanese sounds vowel/ö/, he raises vocal fold vibration than when he sounds vowel / / Auditorily, when we hear vowel /ö/ and vowel / /. We can hear that vowel /ö/ has higher pitch than vowel / /. The broadband spectrogram (picture 11) is another evidence of how vowel //ö/ both in opened syllable and in closed syllble was realized with higher Fo than the realization of the vowel / /. The pitch contour of the vowel/ö/ in the word leubeut (second contour) is relatively higher than Fo contour of the vowel $/ /$ in the word lebet (first contour). The contours show that vowel /ö/ (in Sundanese) is realized with higher frequency of vocal fold vibration than the realization of the vowel / /.

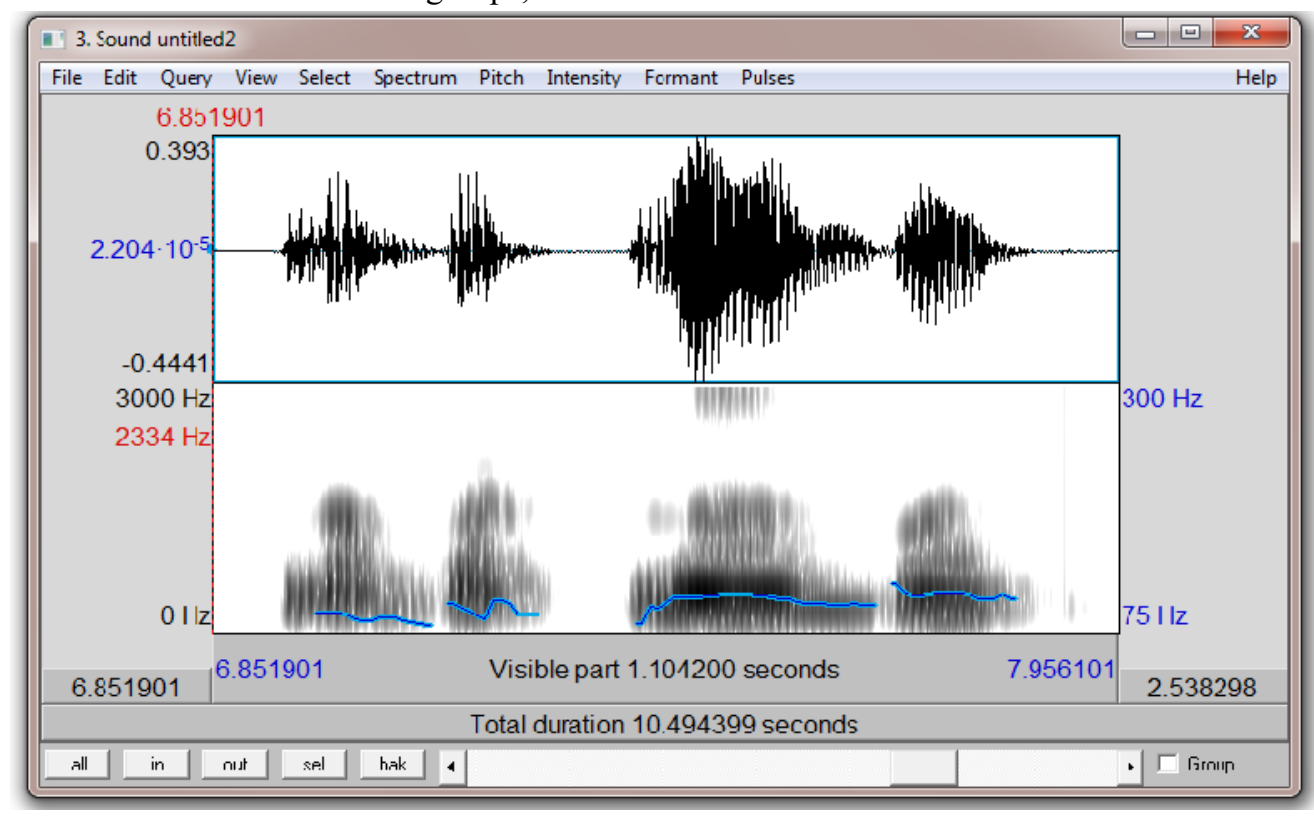

Pic. 11: Pitch contour (second dotted line from below) of the word lebet and leubeut spoken by informan with window length $20 \mathrm{~ms}$

\subsection{Duration}

Duration is an aspect that colours a sound. The aspect of duration always characterizes a sound because the time length of sounds defines temporal structure of speech. This research found that, in Sundanese, vowel / / has shorter duration than vowel /ö/. If we refer to table 1 , we can identify that duration mean of vowel / / in opened syllable (first syllable)) has lower value than duration mean of vowel /ö/ (second syllable). The duration mean of vowel / / is 197milisecond (ms), while duration mean of vowel /ö/ is $284 \mathrm{~ms}$. The acoustic distance between the two means is $57 \mathrm{~ms}$. A T-test (two tailed independence sample test) was done to assess whether the means of the two groups, duration of vowel / / and duration of vowel /o/ is statistically different. The result shows that there is a significant difference between the 
duration means of the two vowels in opened vowel $(\mathrm{p}=0,000 ; \mathrm{p}<0,05)$.

The data in table 2 shows the same nature like table 1. The duration means of vowel / / in closed syllable has lower value than the duration means of vowel /ö/ at the same syllable. The duration mean of vowel / / is 120milisecond (ms), while duration mean of vowel /ö/ is $166 \mathrm{~ms}$. The acoustic distance between the two means is $46 \mathrm{~ms}$. T-test (two tailed independence sample test) shows that there is a significant difference between the duration means of the two vowels in closed vowel $(p=0,000 ; p<0,05)$.

The acoustic data both in table 1 and table 2 indicates that physiologically Sundanese speakers sound vowel / / with shorter duration than vowel /ö/. This also indicates that hearers would hear vowel /o/ with longer duration than vowel / /. The broadband spectrogram (picture 12 and 13) is an evidence of how vowel /ö/ both in opened syllable and in closed syllble is realized with longer duration than the realization of the vowel / /.

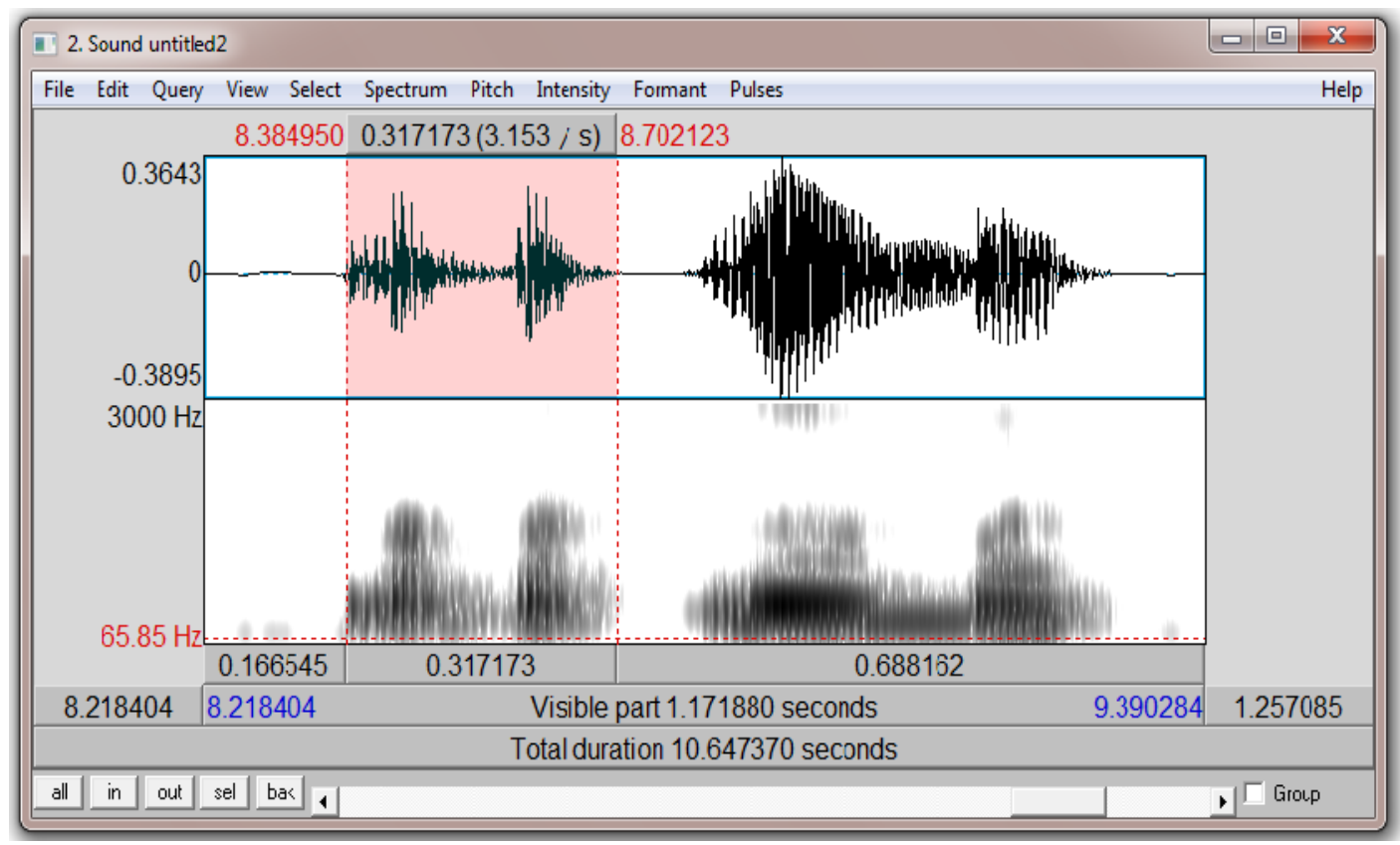

Picture 12

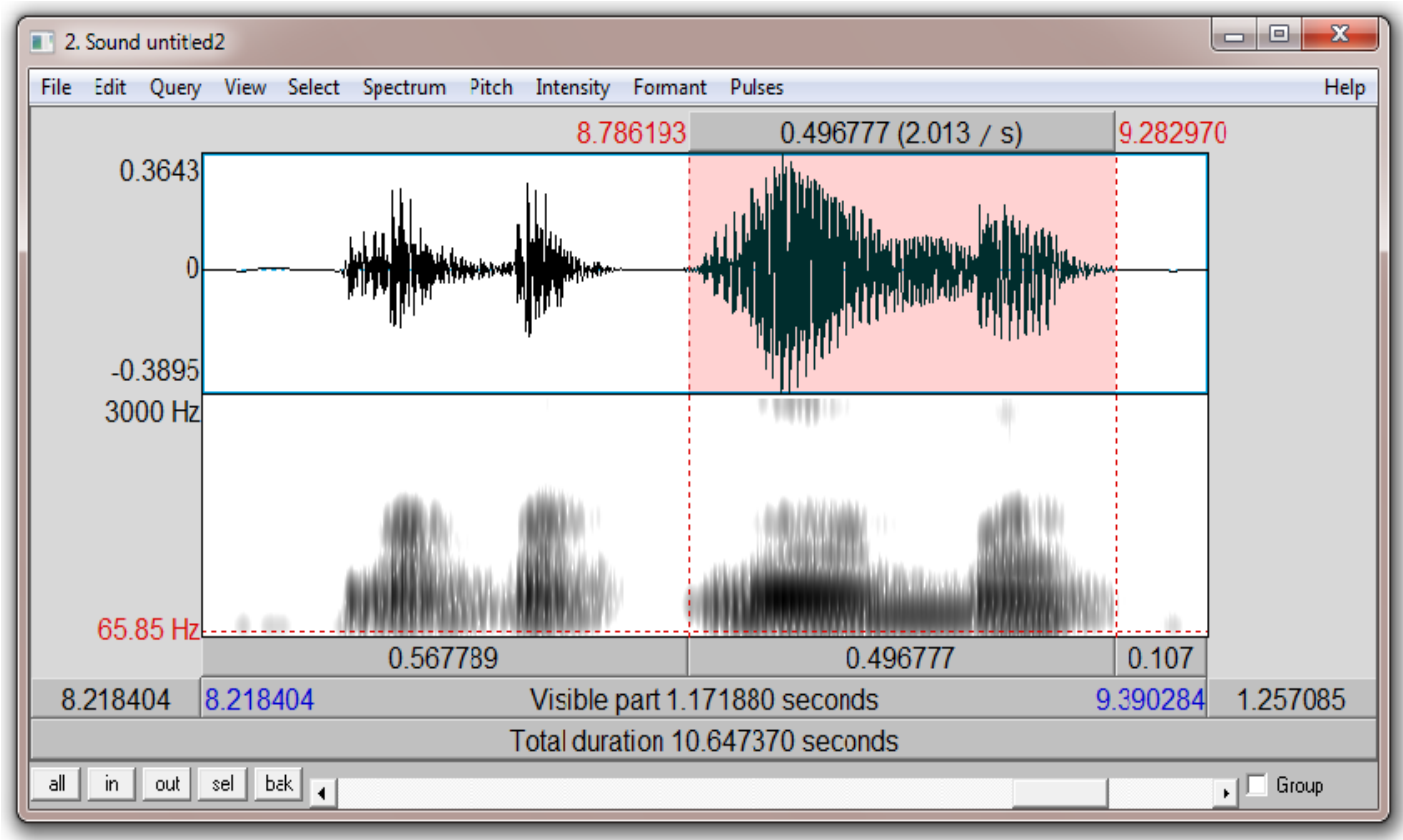

Picture 13 
Picture 12 and 13 above show wave form and spectrogram of the minimal pair lebet $\left[\begin{array}{lll}1 & b & t\end{array}\right]$ 'come in' and leubeut [löböt] 'very fruitful". We can compare between the two pictures that the word lebet has shorter duration, while the word lebeut has longer duration. Picture 12 shows that when we block wave form or spectrogram of the lebet. It shows $317 \mathrm{~ms}$. On the other hand, when we block wave form and spectrogram of the word leubeut (picture 13), it shows 496ms. This indicate that vowel / / has shorter duration than vowel /ö/.

\subsection{Intensity}

The last acoustical analysis of this research is intensity. As it is explained before, perceptually intensity is perceived as loudness of speech sound. Physiologically, the degree of intensity is greatly influenced by the air capacity which passes through the glottis. A stronger air flow would create a higher intensity.

Contrastive data analysis between vowel / / and /ö/ shows that intensity value of vowel /ö/ is higher than intensity value of vowel / /. The data in table 1 shows that the intensity means of vowel /ö/ at the opened syllable (first syllable) is higher $(77 \mathrm{~dB})$ than the intensity mean of vowel / / at the same syllable $(71 \mathrm{~dB})$. The acoustic distance between the two values is $6 \mathrm{~dB}$. The lowest intensity of vowel /o/ 74 decibel (dB) and the highest intensity is $81 \mathrm{~dB}$. On the other side, The lowest intensity of vowel / / 67 decibel (dB) and the highest intensity is $75 \mathrm{~dB}$. A T-test (two tailed independence sample test) shows that there is a significant difference between the intensity mean of the two vowels in opened vowel $((p=0,000 ; p<0,05)$.

Similar analysis has been done too for the intensity of vowel / / and /ö/ at closed syllable (second syllable). And again. we found the same data characteristics as the data in table 1. From data in table 2, we found that vowel /ö/ has higher intensity than vowel / /. The intensity mean of vowel / / at closed syllable is lower than the intensity of vowel /ö/at the same syllable. The intensity mean of vowel / / 72, while the intensity mean of vowel /ö/ is 74 . The acoustic distance of the two value is $2 \mathrm{~dB}$.

The data, we have explained, indicates that physiologically sundanese speakers give higher energy of air flow when they sound vowel /ö/ than they sound vowel / /. In consequence, perceptually vowel /ö/ sounds harder than vowel / /. A broadband spectrogram (picture 14) is a strong supporting evidence of how vowel //ö/ both in opened syllable and in closed syllble is realized with higher intensity than the realization of the vowel / /. The intensity contour of the vowel/ö/ in the word leubeut (second contour) is relatively higher than intensity contour of the vowel /o/ in the word lebet (first contour). The contours represent that vowel /ö/ (in Sundanese) is realized with higher air pressure than the realization of the vowel / /.

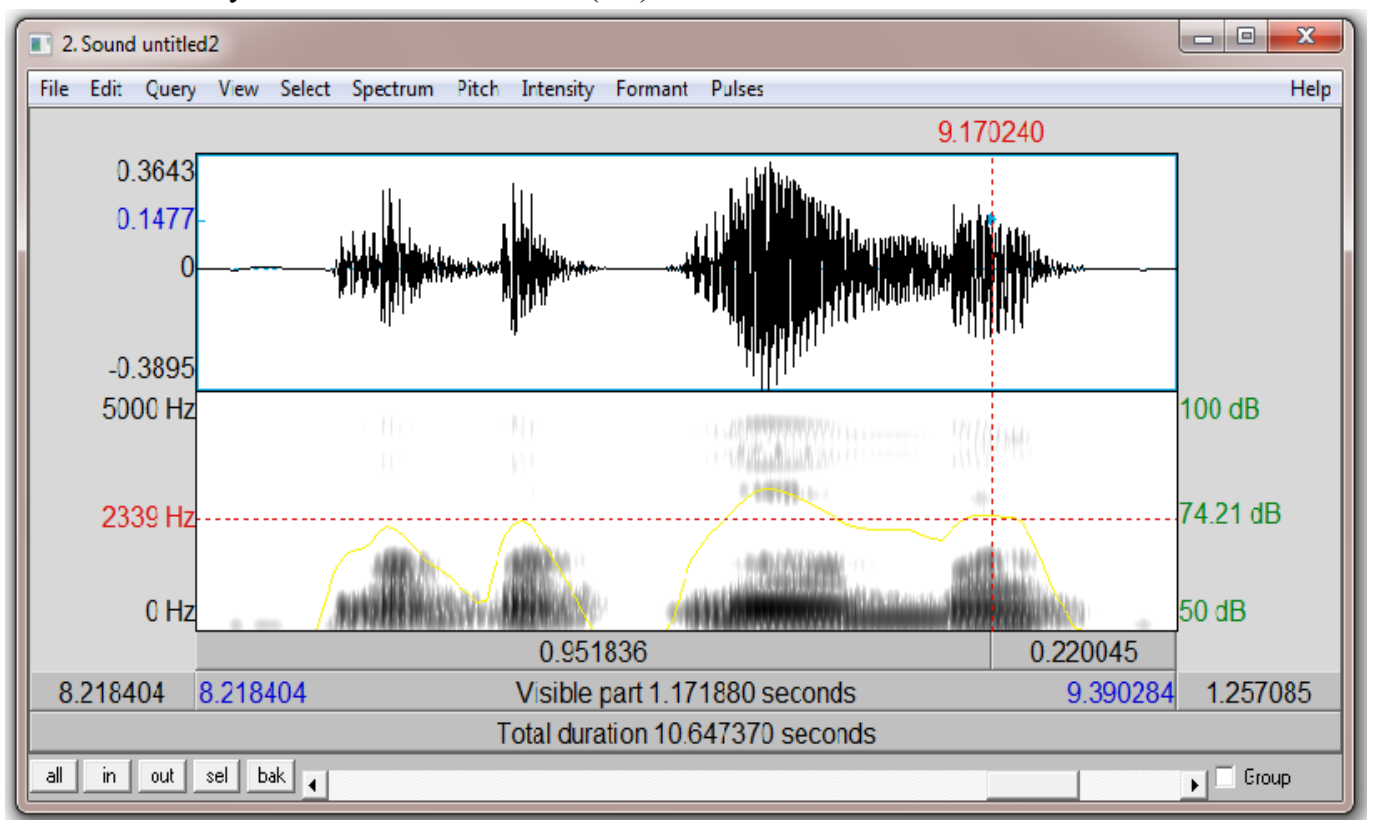

Pic. 14: Intensity contour of the vowel / / in the word lebet (first contour) and intensity contour of the vowel /ö/ in the word leubeut (second contour) 


\section{CONCLUSION}

\subsection{Conclusion}

This experimental phonetic research was intended to search general acoustic properties of two Sundanese central vowels, viz / / and /ö/ and to search the acoustic contrasts between the two vowels. The result of the research specifically has been explained in the previous section. Now, we come to the section in which we affirm our claims.

In correlation with the first objective of the research viz. to find the general profile on the two Sundanese central vowels, we found that vowel / / has higher F1 than vowel /ö/ both at opened syllable and at closed syllable. However, for the other acoustic properties, viz the second formant (F2), fundamental frequency (Fo), duration (ms), and intensity (dB), vowel /ö/ has higher acoustic values than vowel / /.

In correlation with the second research question, viz what acoustic properties the two vowels contrast each other, we found that all acoustic properties (F1, F2, Fo, duration and intensity) contrast the two Sundanese central vowels. All statistical tests, we applied, show the results that there are significant differences between the acoustic properties belong to each vowel.

Based on the acoustic findings we got, we can explain that (1) sundanese realize the vowel / / with lower tongue position than the vowel /ö/. This conclusion based on the fact that vowel / / has higher F1 than vowel /o/. So, this conclusion is in line with the vowel chart proposed by Sugiyono (2006), Crother (1978 in van Zanten 1989), and Sudaryat, et al. (2010). (2) Sundanese realize vowel /ö/ with frontier part of tongue than the realization of vowel / /. This conclusion based on the fact that vowel /ö/ has higher F2 than vowel / /. This findings is opposed with Crother (1978 in van Zanten 1989), and Sudaryat, et al. (2010) who locate the two vowels straightly in vertical dimension. However, this research finding corresponds positively with vowel chart proposed by Sugiyono (2006) which locates vowel /ö/ frontier than vowel / /. (3) physiologically, Sundanese raise vocal fold vibrations for vowel /ö/ than when they sounds vowel / /. In consequence, auditorily we hear vowel /ö/ with higher pitch than we hear vowel / /. We know it from the acoustic fact that fundamental frequency (Fo) of vowel / / is lower than vowel /ö/. (4) Another acoustic property, duration, shows that vowel / / has shorter duration than vowel /o/. It means that physiologically Sundanese sounds vowel /ö/ with longer duration than vowel / /. It also indicates that air stream for /ö/ is longer than vowel / /. (4) the last, based on the acoustic fact we gained, we claim that physiologically Sundanese speakers give higher energy of air flow when they sound vowel /ö/ than when they sound vowel / /. The fact shows that intensity value of vowel /ö/ in decibel scale (dB) is higher than vowel / /. So, it implies to the auditory sensation that vowel /o/ is heard harder than vowel / $/$.

\subsection{Suggestion}

The conclusions of this research have been delivered. In this section, we would like to express our suggestion for further researches. First, this research only studies two Sundanese central vowels. We haven't touched all Sundanese vowels. So, There is still an opened area for other researchers to study those vowels. Second, we suggest that researchers to apply a speech analyzer. This instrument will be helpful to make an accurate analysis than we only apply auditory capacity. The last, Sundanese sound system is still a broad area to study. Sundanese prosodic system is one topic which until now only a few people study it. So, we would like to suggest others to study Sundanese prosodic system.

\section{BIBLIOGRAPHY}

Alieva, N.F., V.D. Arakin, A.K. Oglobin \& Yu.H. Sirk (1991). Bahasa Indonesia: Deskripsi dan Teori (translation). Seri ILDEP. Yogyakarta: Kanisius.

Alwi, H., S. Darjowjidojo, H. Lapoliwa, \& A.M. Moeliono (2003). Tata Bahasa Baku Bahasa Indonesia. Jakarta: Balai Pustaka. 
Ball, M.J. \& N. Muller (2005). Phonetics for communication disorder.USA: Lawrence Erlbaum Associates.

Clark, J. \& C. Yallop (1990). An Introduction to Phonetics \& Phonology. Cambridge, Massachusetts: Basil Blackwell.

Coolsma, S. 1985. Tata Bahasa Sunda, (translated by Hussein Widjajakusukah and Yus Rusyana from Soendaneesche Spraakkunst. Jakarta; Djambatan.

Ebing, E. (1997). Form and Function of Pitch Movements in Indonesian. Leiden: Research School CNWS.

Hart, J.'t., R. Collier \& A. Cohen (1990). A Perceptual Study of Intonation. Cambridge: Cambridge University Press.

Hayward, K. (2000). Experimental Phonetics. Pearson Education: Edinburg.

Kats, J. And Soeriadihardja. 1933. Tata Bahasa dan Ungkapan Bahasa Sunda. (translated by Ayatrohaedi from Spraakkunst en Taaleigen van het Soendaasch Deel 1A: Inleiding. Batavia: Visser \& Co Seri ILDEP. Jakarta: Djambatan.

Ladefoged, P. (2003). Phonetic Data Analysis. Oxford: Black Publishing.

Lehiste, I. (1970). Suprasegmental. Massachussets: Massachussets Institute of Technology.

Robins, R. H. 1983. Sistem dan Struktur Bahasa Sunda. (translated by Harimurti Kridalaksana). Jakarta: Djambatan.

Sugiono, Shinutama. 2006. Stratifikasi Sosial Interferensi Fonetis Bahasa Sunda-Indonesia. Bandung: Eja Insani.

Sudaryat, Yayat dkk. 2007. Tata Bahasa Sunda Kiwari. Bandung: Yrama Widya.

Van Zanten, Ellen. 1989. Vokal-Vokal Bahasa Indonesia. (translated by Lukman Hakim from The Indonesian Vowels: Acoustic and Perceptual Exsplorations). Jakarta: Balai Pustaka.

\section{APPENDICS}

Table 1

Acoustic properties of vowel / / and /ö/ at the opened syllable of the minimal pair $\left[\begin{array}{lll}1 & b & t\end{array}\right]$ and [löböt $]$

\begin{tabular}{|c|c|c|c|c|c|c|c|c|c|c|}
\hline No. & F1 ә & F10̈ & F2 ә & F2 ö & $\mathrm{Hz}$ ә & Hz ö & ms ə & ms ö & $\mathrm{db}$ ə & $\mathrm{db} \ddot{0}$ \\
\hline 1 & 459 & 418 & 778 & 1223 & 96 & 105 & 204 & 294 & 70 & 81 \\
\hline 2 & 616 & 413 & 1286 & 1242 & 95 & 103 & 212 & 294 & 74 & 80 \\
\hline 3 & 444 & 418 & 664 & 731 & 98 & 107 & 188 & 288 & 74 & 79 \\
\hline 4 & 441 & 413 & 733 & 1182 & 93 & 104 & 192 & 268 & 70 & 80 \\
\hline 5 & 656 & 419 & 1302 & 637 & 93 & 107 & 238 & 316 & 73 & 77 \\
\hline 6 & 455 & 417 & 799 & 1322 & 89 & 105 & 248 & 278 & 70 & 80 \\
\hline 7 & 480 & 407 & 775 & 1026 & 87 & 103 & 206 & 266 & 71 & 81 \\
\hline 8 & 478 & 420 & 533 & 1369 & 96 & 105 & 216 & 316 & 73 & 81 \\
\hline 9 & 467 & 426 & 754 & 1283 & 92 & 107 & 184 & 307 & 71 & 80 \\
\hline 10 & 472 & 425 & 771 & 1154 & 92 & 107 & 181 & 312 & 71 & 79 \\
\hline 11 & 307 & 417 & 678 & 802 & 92 & 104 & 223 & 305 & 72 & 81 \\
\hline 12 & 479 & 414 & 1331 & 1408 & 93 & 107 & 198 & 266 & 72 & 75 \\
\hline 13 & 578 & 422 & 1274 & 1321 & 94 & 106 & 206 & 282 & 74 & 79 \\
\hline 14 & 641 & 422 & 1261 & 685 & 91 & 109 & 182 & 235 & 67 & 75 \\
\hline
\end{tabular}


Yusup Irawan: An Acoustical Contrastive Analysis of Sundanese Central Vowels

\begin{tabular}{|c|c|c|c|c|c|c|c|c|c|c|}
\hline 15 & 499 & 422 & 1244 & 754 & 98 & 105 & 170 & 261 & 75 & 79 \\
\hline 16 & 671 & 425 & 1128 & 964 & 89 & 108 & 179 & 286 & 70 & 79 \\
\hline 17 & 476 & 410 & 590 & 560 & 96 & 106 & 221 & 271 & 72 & 79 \\
\hline 18 & 528 & 429 & 546 & 1151 & 97 & 108 & 202 & 296 & 72 & 77 \\
\hline 19 & 491 & 431 & 724 & 1188 & 97 & 109 & 182 & 298 & 72 & 75 \\
\hline 20 & 437 & 424 & 652 & 1382 & 99 & 106 & 176 & 281 & 71 & 80 \\
\hline 21 & 591 & 452 & 1211 & 1421 & 95 & 111 & 264 & 286 & 73 & 77 \\
\hline 22 & 492 & 443 & 656 & 1314 & 95 & 109 & 214 & 291 & 72 & 76 \\
\hline 23 & 526 & 438 & 1196 & 1343 & 98 & 110 & 191 & 297 & 72 & 76 \\
\hline 24 & 474 & 436 & 1187 & 1325 & 91 & 111 & 192 & 296 & 69 & 74 \\
\hline 25 & 400 & 406 & 1331 & 465 & 95 & 108 & 176 & 294 & 69 & 78 \\
\hline 26 & 571 & 447 & 712 & 1440 & 94 & 119 & 208 & 240 & 71 & 75 \\
\hline 27 & 540 & 426 & 1321 & 1414 & 95 & 109 & 189 & 293 & 73 & 75 \\
\hline 28 & 554 & 425 & 1230 & 958 & 95 & 108 & 188 & 289 & 73 & 75 \\
\hline 29 & 449 & 423 & 686 & 551 & 95 & 109 & 181 & 272 & 70 & 74 \\
\hline 30 & 451 & 455 & 782 & 1312 & 87 & 110 & 172 & 264 & 71 & 74 \\
\hline 31 & 627 & 440 & 1234 & 1410 & 94 & 117 & 198 & 271 & 71 & 74 \\
\hline 32 & 518 & 426 & 1308 & 1412 & 96 & 109 & 191 & 298 & 73 & 75 \\
\hline 33 & 519 & 430 & 1108 & 1087 & 95 & 108 & 182 & 294 & 73 & 76 \\
\hline \multirow[t]{2}{*}{34} & 450 & 412 & 688 & 497 & 94 & 108 & 171 & 272 & 71 & 74 \\
\hline & 506.971 & 425.029 & 955.088 & 1098.03 & 94 & 107.85 & 197.79 & 284.62 & 71.618 & 77.353 \\
\hline
\end{tabular}

Table 2

Acoustic properties of vowel / / and /ö/ at the closed syllable of the minimal pair [l $\left.\begin{array}{lll}1 & b\end{array}\right]$ and [löböt]

\begin{tabular}{|c|c|c|c|c|c|c|c|c|c|c|}
\hline No. & F1 ә & F10̈ & F2 ә & F2 ö & Hz ә & Hz ö & ms ə & ms ö & db $ә$ & $d b$ ö \\
\hline 1 & 504 & 402 & 700 & 759 & 95 & 110 & 143 & 173 & 74 & 75 \\
\hline 2 & 425 & 417 & 752 & 673 & 91 & 105 & 127 & 162 & 72 & 80 \\
\hline 3 & 491 & 389 & 625 & 1215 & 97 & 105 & 128 & 150 & 74 & 76 \\
\hline 4 & 453 & 420 & 511 & 676 & 95 & 107 & 121 & 163 & 71 & 79 \\
\hline 5 & 484 & 388 & 771 & 881 & 87 & 110 & 116 & 153 & 72 & 75 \\
\hline 6 & 455 & 432 & 751 & 1379 & 87 & 110 & 128 & 153 & 71 & 76 \\
\hline 7 & 429 & 446 & 726 & 1283 & 90 & 111 & 110 & 162 & 72 & 75 \\
\hline 8 & 454 & 428 & 781 & 1086 & 89 & 110 & 118 & 115 & 89 & 77 \\
\hline 9 & 459 & 420 & 744 & 730 & 93 & 109 & 112 & 165 & 72 & 74 \\
\hline 10 & 466 & 447 & 660 & 1305 & 94 & 110 & 111 & 146 & 72 & 74 \\
\hline 11 & 649 & 427 & 1099 & 750 & 92 & 111 & 133 & 158 & 73 & 76 \\
\hline 12 & 442 & 422 & 715 & 900 & 90 & 106 & 125 & 168 & 71 & 79 \\
\hline 13 & 617 & 395 & 994 & 742 & 91 & 111 & 115 & 172 & 72 & 76 \\
\hline 14 & 399 & 478 & 719 & 1202 & 92 & 113 & 87 & 175 & 70 & 73 \\
\hline 15 & 499 & 411 & 863 & 582 & 93 & 109 & 127 & 161 & 73 & 75 \\
\hline 16 & 457 & 405 & 762 & 690 & 87 & 115 & 122 & 183 & 72 & 73 \\
\hline 17 & 453 & 380 & 740 & 724 & 92 & 113 & 115 & 160 & 71 & 73 \\
\hline 18 & 568 & 411 & 588 & 752 & 94 & 111 & 131 & 177 & 73 & 74 \\
\hline 19 & 376 & 409 & 561 & 829 & 98 & 112 & 111 & 188 & 73 & 74 \\
\hline 20 & 469 & 375 & 679 & 835 & 94 & 115 & 121 & 170 & 73 & 72 \\
\hline
\end{tabular}




\begin{tabular}{rrrrrrrrrrrr}
\hline $\mathbf{2 1}$ & 447 & 459 & 735 & 1156 & 92 & 115 & 113 & 159 & 71 & 75 \\
$\mathbf{2 2}$ & 492 & 515 & 737 & 1334 & 89 & 114 & 123 & 163 & 71 & 73 \\
$\mathbf{2 3}$ & 492 & 521 & 737 & 1139 & 92 & 114 & 117 & 173 & 71 & 73 \\
$\mathbf{2 4}$ & 463 & 433 & 724 & 1195 & 92 & 110 & 111 & 173 & 71 & 75 \\
$\mathbf{2 5}$ & 461 & 440 & 657 & 779 & 94 & 111 & 124 & 211 & 71 & 76 \\
$\mathbf{2 6}$ & 554 & 402 & 673 & 782 & 90 & 117 & 111 & 184 & 73 & 73 \\
$\mathbf{2 7}$ & 632 & 483 & 1252 & 1140 & 91 & 113 & 135 & 205 & 70 & 73 \\
$\mathbf{2 8}$ & 451 & 436 & 675 & 602 & 94 & 117 & 122 & 163 & 71 & 73 \\
$\mathbf{2 9}$ & 522 & 432 & 844 & 1031 & 95 & 114 & 132 & 156 & 73 & 72 \\
$\mathbf{3 0}$ & 456 & 427 & 611 & 1097 & 94 & 112 & 118 & 176 & 71 & 73 \\
$\mathbf{3 1}$ & 546 & 490 & 975 & 1137 & 91 & 113 & 137 & 171 & 70 & 73 \\
$\mathbf{3 2}$ & 446 & 420 & 749 & 661 & 92 & 117 & 121 & 157 & 71 & 73 \\
33 & 539 & 434 & 1437 & 1038 & 95 & 114 & 123 & 155 & 73 & 72 \\
34 & 457 & 427 & 787 & 1104 & 94 & 112 & 121 & 174 & 71 & 73 \\
35 & 485.5 & 430.03 & 774.529 & 946.706 & 92.2353 & 111.6471 & 120.853 & 166.8824 & 72.2941 & 74.5 \\
\hline
\end{tabular}

